\title{
Artificial Intelligence: Serving American Security and Chinese Ambitions
}

http://doi.org/10.21272/fmir.4(3).42-52.2020.

Hassan Obeid, ORCID: https://orcid.org/0000-0002-1329-0217

PhD, Professor, European Business School - Paris, INSEEC U Research Center, Paris, France

\section{Fatima Hillani,}

Master of research (MRes), Lebanese University, Faculty of Economics and Business Administration, Beirut, Lebanon

\section{Rana Fakih,}

Master of research (MRes), Lebanese University, Faculty of Economics and Business Administration, Beirut, Lebanon

\section{Kholoud Mozannar,}

Master of research (MRes), Lebanese University, Faculty of Economics and Business Administration, Beirut, Lebanon

\begin{abstract}
In recent years artificial intelligence has entered a new era, which gives rise to many hopes for powerful states such as the United States and China. In this paper, we analyze the importance and role of artificial intelligence in technological development in each of the two countries on the one hand, and its influence on ChinaAmerican relations in terms of technological and geopolitical conflict. To get the right results, we rely on a literature review of dozens of articles published on the phenomenon in order to compare the power of artificial intelligence between the United States and China where we found that the US still has technological strength, especially in the field of artificial intelligence, but we can say that a large force is beginning pose a threat for it which is China that has great technological capabilities so, we can say that the United States should work more in this field. Also, we found that artificial intelligence has a primary goal in both countries, it helps China to achieve its ambitions to be the leader of the world, and this intelligence, on the other hand, provides protection and security to the United States. This paper is divided into three sections. The first section focuses on the importance of artificial intelligence in achieving China's ambitions, the second section explains the role of artificial intelligence in the US protection service, and the third section describes the technological and geopolitical conflict resulting from the competition in artificial intelligence between these two countries.
\end{abstract}

Keywords: Artificial intelligence, United States, China, Conflict, leader.

JEL Classification: O30, O38, F51.

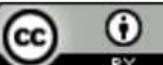

Cite as: Obeid, H., Hillani, F, Fakih, R., Mozannar, K. (2020). Artificial Intelligence: Serving American Security and Chinese Ambitions. Financial Markets, Institutions and Risks, 4(3), 42-52. http://doi.org/ 10.21272/fmir.4(3).42-52.2020.

(C) The Authors, 2020. This article is published with open access at Sumy State University.

\section{Introduction}

The first applications to Artificial Intelligence technologies ran out to some extent (such as heuristics, framebased representations, complacency with constraints, rule-based reasoning, logic programming, and blackboards) were limited in nature because they were based only on geometric representations of design objects and did not drive to much interest in the design process (Smithers, 1989). Since 1991, several scientific events in AI have dealt specifically with context (Maskery, H.-Meads, 1992). A survey by Patrick Bresilon (1999) at the University of Paris 6 showed that efforts in artificial intelligence are mainly concerned with representing context intertwined with knowledge. In addition, Paul Cohen (1991) found that the behavior of 
AI systems is an artificial phenomenon. A survey of experimental conflict studies conducted by S.M. Easterbrook, EE Beck, JS Goodlet, L. Plowman, M. Charples, CC Wood showed that conflict is a common phenomenon in interactions between individuals and groups of individuals. An essay by Daniel J. Olscher (2015) shows that if we can use the power of accurate and culturally aware AI to understand, infer and delve into human data, it appears that it is possible to understand others more deeply and thus find new solutions to problems that eluded us in the past.

The United States and China are the two main powers in the world during this century. Some think that the China-American conflict is the subject of a new discussion in the geopolitical field. But the truth is that the China-American conflict is not a new subject, since its roots go back to the early 70 s of the latest century. The conflict began to manifest itself in the 1990s, especially after the collapse of the Union and after the September 11,2001 incident.

However, this hostility and this conflict between the two countries have become a challenge to acquire a leadership position in the world. For this, China and America use many different weapons to realize their political, geographic, and commercial interests. Artificial Intelligence is one of the tools that both countries are using to achieve their goals.

Today, artificial intelligence is extremely important because of its main role in the economy world and in international relations. Even more that we are seeing new terms related to it such that cyber war, cyber space, soft power, hard power and other. Such a subject makes us assume many hypotheses concerning the ChineseAmerican conflict in the field of artificial intelligence. Therefore, how China and the United States use artificial intelligence to compete? Is China a real competitor to the United States in the field of artificial intelligence? Or the United States are the only great power in the world? Can China follow the United States in artificial intelligence or exceed it?

To answer these questions, this article was written on the basis of scientific research, geopolitical analyzes and precise statistics related to the subject studied. These ideas presented were also supported by appropriate examples. Moreover, the effects of artificial intelligence have been studied in China and the United States at numerous different levels, politically, economically, technologically, and militarily.

\section{Section 1: Artificial intelligence serving China's ambitions}

Artificial intelligence occupies a growing place in the international economy today. China, which is one of the world powers, is one of the main competitors in this field, in terms of its means of development and its strategies. Artificial intelligence then becomes a technological challenge on one hand, and a means to achieve China's leadership ambitions on the other. The development of the latter has many consequences in the field of international relations and geopolitics (Henri Kissinger 2018). For example, the rise of the Chinese company "Huawei" in the field of the fifth generation (5G) network was accompanied by sanctions imposed by Washington Under the pretext that this company is a tool of influence of the Chinese party-state (Xavier Seurre 2020: 2). It seems then that artificial intelligence is increasingly becoming an issue of sovereignty and power for states, multinational firms and other non-state factors. On the Chinese side, artificial intelligence represents an object of a state strategy aimed at coordinating the actions of the country's political, economic, social, and military forces (Xavier Seurre 2020: 3). In the Republic of China, the work of Qiao Liang and Wang Xiangsui, authors of "War Without Limits", has prompted Chinese leaders to view the field of information and communications technology as an asymmetric way of competing with the American hyper power in the world. The Chinese leaders, from Deng Xiaoping ${ }^{2}$ to $\mathrm{Hu} \mathrm{Jintao}^{3}$, have laid the foundations for the development of a whole spectrum of unconventional means aimed at perfecting Chinese power and at the same time weakening American power.

\section{The Chinese State in the digital and cyberspace domain: A major and inevitable player}

During the period 1980-1990, the Chinese state supported Chinese private companies in the technological and digital field, named BHATX, bringing together five major companies in this field: Baidu (search engine), Huawei (telecommunications and telephony), Alibaba (commerce on the Internet), Tencent (online messaging and video games) and Xiaomi (telephony). These Chinese companies, which are growing in power, represent

\footnotetext{
1 "War Out of Limits" is an exceptional document on current Chinese strategic thinking. Authors Qiao Liang and Wang Xiangsui, two colonels of the Chinese Air Force, shed light on the Chinese perception of new conflicts and tensions in the world.

${ }^{2}$ Deng Xiaoping was a Chinese politician who was the paramount leader of the People's Republic of China from 1978 until 1989.

${ }^{3} \mathrm{Hu}$ Jintaois a Chinese politician who was the paramount leader of China from 2004 to 2012.
} 
the main engine of the development of artificial intelligence. In addition, the BHATX represent a geoeconomics tool to realize the ambitions of the central power of China to become a dominant world power (Emmanuel Meneut 2017).

In October 2017, the Chinese Minister of Science and Technology launched a call for tenders for 13 publicly funded technology projects completed through 2021. These projects enable a very important artificial intelligence chip. After a month, Baidu, Alibaba, Tencent, and voice recognition specialist iFlytek became the first members of the "national AI team" (Fischer, Sophie-Charlotte 2018: 4).

The Chinese company Huawei, which is a pure product of socialist capitalism, represents an economic miracle and symbolizes the transition from Made in China to Made by China (Nicolas Baverez 2019). The strategy of this company is based mainly on innovation. In 2018, Huawei spent $\$ 13.8$ billion on research, with 14 research and development centers around the world and a team of 80,000 engineers (Étienne Gernelle, Guillaume Grallet 2019). Huawei's position in the artificial intelligence sector is evident in its dominance in fifth generation $(5 \mathrm{G})$ network infrastructure, with three years of growth over its competitors. A note from the National Security Council that "networks have become a field of competition" and that "China dominates this field, because it has achieved a hegemonic position in network infrastructure" and that "whoever dominates 5G will be dominant in the Internet of Things and artificial intelligence sector"4.

Other Chinese companies are interested in the development of artificial intelligence. For example, Baidu announced in 2017 the opening of its second research institute in Silicon Valley ${ }^{5}$. Additionally, Tencent has established a new artificial intelligence center in Seattle ${ }^{6}$ (Fischer, Sophie-Charlotte 2018: 4).

In 2020, China announced its progress in building the artificial sun, which is expected to be completed before the end of this year (China National Nuclear Corporation, Southwestern Institute of Physics 2020). It is a device intended for nuclear fusion, where its temperature is estimated to reach 360 million degrees Fahrenheit, it is in fact like 12 suns combined. The increase in temperatures leads to the fusion of the nuclei, generating energy, which would bring humanity closer to the search for unlimited clean energy, by simulating natural reactions within the sun.

\section{Huge and advanced research}

Chinese artificial intelligence scholar Lee Kai-Fu notes that China benefits from four fundamental pillars allowing the acceleration of artificial intelligence research. The first is having an abundance of data, an important source for businesses and for the state that forces them to transfer their data. The second is that China benefits from skilled entrepreneurs. Thirdly, it benefits from scientific experts. And finally, the presence of a strong political voluntarism on which companies can rely (Xavier Seurre 2020: 7).

In January 2018, the Xinhua News Agency announced the construction of a huge Artificial Intelligence Campus in Beijing. This could accommodate 400 companies (Fischer, Sophie-Charlotte 2018: 4).

In May 2019, the Beijing Academy of Artificial Intelligence released the "Beijing Consensus". It is a 15article document that presents principles for the research, development, use and good governance of artificial intelligence (Fischer, Sophie-Charlotte 2018: 4). An unprecedented case, it was the first time that an official Chinese organization has enacted ethical principles in this area.

In addition, a Big Data forum is organized every year by Guiyang City, which is considered the future city of artificial intelligence in China. This forum is essential for the municipality of Guiyang as it enables the economic development of one of the poor regions of the country. The same goes for the Zhongguancun district in Beijing, which attracts Chinese companies to invest in research centers or development parks (Xavier Seurre 2020: 7).

\footnotetext{
4 «Secure 5G : The Eisenhower National Highway System for the Information Age», National Security Council of the United States of America, https://docs.house.gov/meetings/IF/IF16/20180130/106810/HHRG-115-IF16-20180130SD1011-U1011.pdf, May 2019.

${ }^{5}$ Silicon Valley designates the high-tech industry hub located in the southern part of the region of San Francisco Bay in the state of California on the west coast of the United States.

${ }^{6}$ Seattle is the largest city in Washington State and in the northwest of the United States.
} 


\section{The Development Plan for a Next Generation of Artificial Intelligence}

Current Chinese President Xi Jinping is working to ensure that China will achieve a place in the international arena as an inevitable power. Its goal is achieved through the development of artificial intelligence. Xi's China dreams of being an "artificial intelligence superpower", especially after the 2016 defeat of world go champion Lee $\mathrm{Sedol}^{7}$ to the artificial intelligence AlphaGo ${ }^{8}$ developed by the company DeepMind ${ }^{9}$ (Xavier Seurre 2020: 5). In July 2017, the Chinese State Affairs Council under the authority of the Minister of Science and Technology released the "Plan for the Development of a Next Generation of Artificial Intelligence." In this plan, Chinese Premier Li Keqiang defined artificial intelligence as "a strategic technology"10. China is investing and financing massively in this area, over the year 2019-2020, 70 billion dollars are invested in total. In contrast, the US federal state has only funded \$ 11 billion for research on artificial intelligence since 2018 (Charles Thibout 2019: 131-142). China aspires according to this plan to reach the United States this year 2020, overtake it in 2025 and become the world leader in the artificial intelligence market in 2030 (Fischer, Sophie-Charlotte 2018: 3).

\section{The Strategic Challenges of Chinese Artificial Intelligence}

There are three essential challenges to the stability of the Chinese state: Social surveillance and control, strong economic growth, and the strengthening of world power (Xavier Seurre 2020: 7-8). According to Xi Jinping, artificial intelligence has become a means of control and surveillance as this technology provides the Chinese state with technical means for social and political control. Chinese companies are still developing its surveillance techniques in an advanced way. For example, the company FaceAll is developing algorithms to perform facial recognition with $99 \%$ accuracy. The same goes for the Watrix company, which has created a facial recognition system where the camera can identify an individual and analyze his behavior according to the way he walks. The work of these and other companies is certainly in the service of the state. In confirmation, the Chinese government obliges Chinese companies to send their data in accordance with a law published in 2017. This law confirms the government's control over Chinese technology companies in terms of surveillance (Xavier Seurre 2020: 8-9).

Artificial intelligence is still an important source of economic growth. According to the plan released in July 2017, the state estimates that the artificial intelligence market will generate 150 billion yuan in 2020, one trillion yuan in 2025 and 10 trillion yuan in 2030 (Meng Jing 2018). Cyberspace and energy specialist Nicolas Mazzucchi announces that "the whole economy will soon work around data", which explains the Chinese government's ambition to invest in the development of this sector. Beijing then invests in a sector that is already revolutionizing several areas such as energy, transport, security, health and others. Some Chinese companies in these fields are already at the forefront of innovation. We can cite for example the companies DJI, world leader in the drones' sector or Hikvision in the field of video surveillance. Specialist Lee Kai-Fu adds that if the data is the oil of the 21st century, then China would potentially be the new Saudi Arabia and that "a real fever of artificial intelligence in Chinese business is currently developing "1" (Xavier Seurre 2020: 9). So, thanks to the development of artificial intelligence, the Chinese economy is able to move from an economy based on product exports to an economy driven by innovation. In addition, the transition from "Made in China" to "Made by China" that President Xi wishes in $2025^{12}$.

In addition, artificial intelligence today represents a powerful weapon, which the Chinese state can benefit from to achieve its strategic interests through hard power and soft power. In terms of hard power, which is seen as the ability of a state to impose its will on another entity by coercion (Morgenthau 1998), President Xi said in 2017 that China aims to "modernize its army" and make it "smarter"13. To achieve its goal, a central commission was created for military and civilian development, and another commission for the orientation of military scientific research. These two commissions express the fact that the development of artificial intelligence is at the service of military development to a certain extent. Thus, China's vision of reducing the

\footnotetext{
${ }^{7}$ Lee Sedol, is a former South Korean professional Go player of 9 dan rank.

${ }^{8}$ AlphaGo is a computer program that plays the board game Go. It was developed by DeepMind Technologies which was later acquired by Google. AlphaGo had three far more powerful successors, called AlphaGo Master, AlphaGo Zero and AlphaZero.

${ }^{9}$ British subsidiary of the American company Google (Alphabet).

${ }^{10}$ The Development Plan for a Next Generation of Artificial Intelligence, 20 July, 2017, https://chinacopyrightandmedia.wordpress.com/2017/07/20/a-nextgeneration-artificial-intelligence-development-plan/

${ }^{11}$ LEE Kai-Fu, AI Superpowers, China, Silicon Valley and the New World Order, New York, Houghton Mifflin Harcourt Publishing Company, 2018 , 43.

${ }^{12}$ According to the guidelines of the Made in China 2025 Plan published in 2016.

13 The Development Plan for a Next Generation of Artificial Intelligence, 20 July, 2017 https://chinacopyrightandmedia.wordpress.com/2017/07/20/a-nextgeneration-artificial-intelligence-development-plan/
} 
costs of future wars is driven by military artificial intelligence, which in turn reduces casualties and increases the effectiveness of new armaments. The Chinese military is reportedly developing not only stealth drones, but also autonomous ground vehicles, autonomous combat tanks, autonomous submarines (Noel Sharkey, 2019). In terms of Softpower, China wishes to improve its image and invest in what we consider to be a new form of power which manifests itself in the capacity of attraction, of influence from one state over another without using coercion (Joseph Nye 2003). Its first issue is the influence of its technology and the efficiency of its business model based on artificial intelligence. The second is in the university plan. Chinese universities are opening up academic courses linked to the study of artificial intelligence. In addition, according to the 2018 Artificial Intelligence Index, China is no further ahead of the United States in the number of articles published on artificial intelligence. To highlight the progress made in artificial intelligence, the CCP's propaganda is once again mobilized, as during the presentation of the Xinhua news agency's news by a robot equipped with artificial intelligence in $2018^{14}$.

So, after all which has been mentioned, we conclude that today China occupies an important place in the economy world which cannot be underestimated, not only at the commercial level, but also at the technological level through the development of artificial intelligence. But China is not the only country concerned by the development of artificial intelligence. In other words, he is not the only representative in the technological field, but in fact, many countries are interested in this regard. It is true that China has taken its place in the technological field, but there are those who compete with it, especially the United States. So, we have to ask the following question: How big is the development of artificial intelligence in China compared to that of the United States? In other words, how advanced is the technology in the United States? What is the role of artificial intelligence in the development of America's technology sector?

\section{Section 2: United States and Artificial Intelligence: Points of Strength \& Weakness}

The United States was the most productive economy during the quarter of a century following the Second World War (Charless S Maier 1977). There are many factors that lie behind this productive economy, and one of these factors is advanced technology in general and artificial intelligence. Thus, the battle for world leadership lies in the most important areas of technological development. So, what are the strengths and weaknesses of American technology?

\section{The Power of American Technology Projects}

The strengths of American technology are numerous but there are five points that require special attention. First, Gafam, which is one of the strongest strengths of Americans (Google, Amazon, Facebook, Apple and Microsoft) all posted higher sales in 2017, according to data compiled by Statista in the Digital Economy Compass 2018. However, each has its own business model. Apple sales reached \$ 229.2 billion in 2017, Google (110.9 billion dollars) and Facebook (40.7 billion dollars). Moreover, Microsoft is the one that diversifies its revenues the most since $62 \%$ of its turnover comes from the sale of its software, Amazon also has several sources of income, but $82 \%$ of its turnover is still made by selling products (JDN Statista ${ }^{15}$ ). Also, the broad scope and the relative openness of the American Basic Research Foundation require a special attention (David Jeremy 1981). We can also add the Size, wealth, openness, and technological development of the US domestic market. In addition to that, the country's ability to produce technological intensive industries, products, and services (John James 1985) is also an important factor. And the constant competitive power and global reach of many US high technological industries (Robert Bruce 1987) therefore, these give America a special strength.

These five points are closely related, as they contribute to the creation of scientific and technological knowledge in addition to many new products and industries. But despite its importance, it cannot alone enable the United States to successfully address technology challenges in the global economy.

\section{The Weaknesses of American Technology Projects}

Without a doubt, the United States will rely on exploiting the strengths of its technology project for sustainable economic development on the one hand, and to ensure its dominance on the other hand (Ronald Fraser 1994).

\footnotetext{
14 "World's First AI News Presenter Debuts in China," Xinhua, November 11, 2018, http://french.xinhuanet.com/2018-11/08/c_137592033.htm, accessed February 2, 2019.

${ }^{15}$ Statista publishes a portal of studies and statistics from more than 18,000 sources.
} 
But it must be noted that there are six interconnected weaknesses, and they are considered one of the biggest obstacles related to technology like the ancient management philosophies, regulatory frameworks, and human resource strategies for many producers of goods and services in the public and private sectors in the United States, the insufficient investment in the U.S. workforce training and continuing education, and the poor quality especially at the non-supervisory level. In addition to that, the insufficient investment by U.S based companies in production processes, factories, and competitive equipment, the low density in the area of civil research and development for the United States economic activity and insufficient scope of the country's civil research and development portfolio, including weak investment in growth and productivity-enhancing technologies that are high risk or difficult for investors to benefit from. Also, the insufficient awareness and interest in emerging technology outside its institutional boundaries by many US companies and federal laboratories and finally the absence of a strong institutional structure for federal technology policy to support national economic development, and the separation of technology policy from domestic and foreign economic policy at the federal level. It must be noted that the weaknesses of American technology are more subtle and interconnected than well-trusted strengths (John A. Alic 2008).

\section{The United States Today: Huge \& Advanced Research}

The American research and development (R\&D) enterprise is important for them not only because of what it creates, but also because of what it reflects from America's technology leadership (Nelson \& Wright 1992). Therefore, the United State objective is to understand the real security concerns that arise when the resources of other countries increase.

However, the Trump Administration recognizes the importance of an open research environment to support artificial intelligence. So, this Administration has already made tremendous progress in ensuring American science and technology (S\&T) leadership. There is a lot of research done by the US administration is carrying out today. For example, President Trump has renewed and accelerated U.S. space exploration by reviving the National Space Council and directing NASA to return astronauts to the Moon in the next five years. Also, Trump Administration launched the American Artificial Intelligence Initiative to ensure artificial intelligence is developed for the benefit of the American people and it put forward a decadal vision for S\&T for America's Oceans, and has taken action to promote the ocean environment and economy. Moreover, the scientists at their national labs discovered a new way to domestically produce at scale medical isotopes to treat prostate cancer. Finally, the White House released a new National strategy on STEM education and Trump directed at least \$200 million per year in grant funding to STEM (including computer science) education.

These are some of the current USA projects where we find them interested in developing scientific research in all fields. Since America believes that as other countries advance, they must also advance which is the primary goal of the Trump administration.

\section{The Impacts of American Artificial Intelligence Technology}

America's artificial intelligence has many effects in several areas, such as: the political level, military level and economic level. At the Political level the technological revolution in general and social networking in particular has become a fact of life for civil society worldwide, involving many actors ( Goldin L, Katz C 2008). So, how does the ubiquity of social media affect U.S interests, and how should U.S policy respond to it? With the intensity of the communication landscape the network residents get more access to information, more opportunities to engage in public discourse, and enhance the ability to take collective action. It has been shown that increased freedoms can help to coordinate audience loosely changing demand, as happened in Spain in 2004, when demonstrations were organized by text message, which led to the rapid overthrow of Spanish Prime Minister Jose Maria Aznar.

Therefore, social media has become almost a formatting tool all the political movements in the world, just like most of the authoritarian movements in the world. In response, the US State Department committed to "Internet freedom" as a specific political goal. It argues for the right of people to freely use the Internet as a policy appropriate to the United States (Carvolho VM 2014)

At the military Level the development of American technology and innovation has done many things as the main military research and development efforts in the war-the Manhattan Project and radar development - have equipped patterns that are still influencing today. The first, which was the largest and most expensive technological institution in history, developed the atomic bomb and affected the structure and management of massive post-war research and development projects in defense, nuclear energy, and space (Neffeki F 2008). 
The Manhattan Project has also created a global focus of talent and physical infrastructure in basic and applied engineering in the United States.

Secondly, radar development has demonstrated the major coordinating role for military users, academic researchers, and industrial companies, and the potential strength of linkages between disciplines and browsers.

So, military research and development had a clear impact on post-war innovation in the United States, and this allowed the United States to establish a leading position in the arms industry, which made it one of the most exporters of weapons (Neffeke F 2008). While at the economic level: technological development can improve living standards, increase productivity (Michell T, 2017), reduce production costs and prices, and raise real wages (Brynjoflsson E,2014). However, border technologies, including artificial intelligence, have the potential to foster new sources of employment and income and access new markets and opportunities that were previously difficult to access. For this reason, the United States, characterized by scientific and technological developments, is the driving force behind science and economics. Thus, policies adopted to ensure economic growth and development brings technological development. However, technological development can eliminate some jobs and fields of work and have a negative impact on employment on the one hand and create new jobs and opportunities on the other hand (Mortensen DT, 1994 / Naone E (2009)).

Finally, the United States gained global leadership in the nineteenth century through the techniques and industries of the "Second Industrial Revolution" where the Second World War stimulated many changes in American innovation. But the question remains:"does America still play its dominant role? Or has China already become a threat to it?"

\section{Section 3: The Race for Artificial Intelligence: China-US Conflict}

"Whoever masters artificial intelligence will be the master of the world," Vladimir Putin said in September 2017 during a meeting with young Russians. Artificial intelligence is seen as the instrument that will allow the regime to strengthen its hold over the population while giving the country the means to achieve its ambitions on the international scene ${ }^{16}$. AI is therefore also a power issue for China, which wishes to deprive the United States of its rank as the world's leading power (Xavier Seurre 2020: 13).

US President Donald Trump officially ordered his administration on Monday, February 11, 2019 to make artificial intelligence a priority, an area where American supremacy could be threatened by China ${ }^{17}$. "Nevertheless, given the speed at which innovation in artificial intelligence is advancing, we cannot remain passive in telling ourselves that our supremacy is guaranteed" the White House wanted in a statement. But, the presidential text does not detail any amount or any strategy to do this.

Cyber-Conflicts and the global battle for influence are strengthening the path for "a major Sino-US confrontation" in the digital realm. Although these two countries have signed a trade truce but their technological rivalry has not disarmed. Both hyper powers are expected to continue to strive for planetary supremacy for years to come ${ }^{18}$.

Washington and Beijing, these two powers which have multiple means to develop innovations and technologies in the field of AI, they own transnational firms, the United States has the GAFAM (Google, Facebook, Amazon and Microsoft) which become geopolitical actors, since in reality they have equal or even greater power than certain states.

Faced with the restrictive conditions instituted by the Chinese state, the American powerful digital firms also failed to penetrate the Chinese market, and in the 1980s and 1990s, the Chinese state supported Chinese private companies in the technological field, which named the BHATX which brings together the five major companies in the digital field (Baidi, Huawei, Alibaba, Tencent and Xiaomi), the latter are now developing AI in an exponential manner. (Xavier Seurre 2020: 14).

The United States has 1763 data centers against 78 for China, even on the financial level, in 2017, the GAFAM generated 648.7 billion dollars in turnover against 164.9 billion dollars for the BHATX ${ }^{19}$. But, in 2018,

\footnotetext{
${ }^{16}$ according to La revue du Digital, published in 2017.

${ }^{17}$ according AFP, published in 2020.

${ }^{18}$ www.Capital.fr, published in 2020.

${ }^{19}$ Idem. 
Alibaba's revenue growth was 56\% when Amazon's was 31\%, Xiaomi 67\% versus Apple's 16\% (Loris Gendreau 2019).

\section{Convergence or non-convergence of interests?}

Since in the United States, we have a neo-liberal logic where we have little state intervention in the economic field, the interests of the American Federal state only very rarely converge with the economic and commercial interests of GAFAM.

On the other hand, in China, the state directs and controls national and private companies according to the public interest, for example, in order to secure the internet by the central government, the bosses of Baidu, Alibaba and Tencent are senior members of the CCP. (Charles Thibout 2019).

Many economists have described China's entry into Cyberplace as entering its own way, under political and economic conditions. In 2017, the Chinese government announced a development plan for artificial intelligence: a budget of 59 billion dollars in 2025 (Charles Thibout 2019). For comparison, in 2018, estimates of the budget allocated by the United States to AI research did not exceed \$ 11 billion ((Xavier Seurre 2020: 6). As a result, some GAFAMs are revising their policies. Industrial to have the ability to compete on the Chinese market as well.

\section{Huawei: an accelerator of the Sino-American conflict}

The company founded by RenZengfei, represents an "economic miracle" (Nicolas Baverez 2019). Ella was able to achieve the world rank in telecommunications and the second rank in the telephony market. Ella clearly presented the passage from imitation to innovation, in another term, the passage from "made in China" to "made by China".

The brand seduces wherever it is established since in 2018 it sold more smartphones than the American Apple, so it is the concrete demonstration of Chinese soft power in the technological field. (Xavier Seurre 2020: 1718).

In addition, Huawei's economic strike force, its technological supremacy in the field of network infrastructure, all these reasons, have implied the disposition of the Chinese firm at the heart of a Sino-American rivalry on the diplomatic, commercial and ideological (Étienne Gernelle 2019).

So, a new perspective is added to the trade war between the United States and China, expressed by the American sanctions against the Chinese firm Huawei, the latter is placed on May 17, 2019 on a blacklist prohibiting it from operating the system of Android operation developed by Google, necessary for the proper functioning of its smartphones produced (Xavier Seurre 2020: 16).

After its dominance in the fifth generation $(5 \mathrm{~g})$ network infrastructure, the US government has noticed the development of China's technology strategy, in comparison with its own less effective neo-liberal strategy, and Huawei is a clear example, which has become the Washington's preferred target, which sees it as a concrete manifestation of the Chinese threat, and if the United States does not act, China could win militarily, economically and politically in the long run. (Xavier Seurre 2020: 18-19).

For this, the United States has adopted trade and economic sanctions against the brand by prohibiting it from obtaining American electronic components essential to its production of electronic equipment, with the aim of slowing down the growth of this Chinese firm which represents a threat to American security.

\section{China facing sanctions}

However, these sanctions will strengthen Chinese efforts to have their own electronic components industry. So, Huawei has a plan B. This is based on the development of a national operating system, called Harmony OS. The trouble this option is expensive.

\section{The patent demand between China and the United States}

The demand for patents is broken down between institutions and companies. On the part of institutions, 17 of the 20 universities and institutions that have filed the most patent applications around the world are Chinese (more than 2,500 patent families relating to machine learning technologies). On the business side, the Americans IBM and Microsoft have the most patent applications (human-computer interaction technologies). 
However, the one that has recorded the highest increase in patent applications is the Chinese electricity giant SGCC (+ 70\% between 2013 and 2016). (Catherine Mommaerts 2019).

\section{The ascending factors from China and descending from the United States}

Several factors can explain the exceptional dynamism of Chinese companies, where first, these firms have great access to data which can make them more efficient, secondly, Chinese companies develop under flexible conditions, in which the government does not impose much on them ethical constraints in addition to the real synergy existing between public and private actors.

The American advance is diminishing, this phenomenon is also due to the political decisions taken in the country. So far, the US government has taken a stance of restraining Chinese investment in AI resources in the US, instead of supporting US potential and confronting its lead. In addition, the United States suffers from a shortage in the number of AI specialists, due to the President's restrictive migration policy. This lack of attractiveness for AI specialists is making the United States difficult to keep pace with technological developments. Chinese companies are already seeing an opportunity to attract top talent. So in the long run, ella could benefit not only from its own efforts, but also from the lack of an AI strategy in the United States.

In addition, science and technology are losing more and more importance in the eyes of government. For example, the Office of Science and Technology Policy (OSTP), which is responsible for advising the President on the impact of science and technology, has been reduced to a quarter of its staff.

Again, there must be a certain emergence between the interests of the private sector, or simply of "GAFAM" and the interests of the government. In the midst of the Sino-American conflict, these companies continue to transfer their skills to China. For example, in December 2017, and while the techno-military rivalry between the two countries crystallizes around this technology, Google is staging its return to Beijing with the opening of an AI research and training center intended for Chinese engineering community. (Charles Thibout 2019)

The US job market opens more than 500,000 computer jobs each year. However, only 43,000 Americans graduate in computer science from US universities each year. The available positions are filled by foreigners.

For several months, a new target in the technological war between the United States and China has appeared, which is China Telecom. The US departments of justice, state, commerce and homeland security have asked the Federal Communications Commission (FCC) to revoke all authorizations granted to the US subsidiary of China Telecom and curb its operations, which could turn it into a Trojan horse for economic espionage, disruption and hijacking of US communications by the Chinese government ${ }^{20}$.

So, China has made efforts in the field of AI, enabling it to become a leader in this field by 2030 . These efforts by Beijing to make the economy more and more innovative, modernize its armed forces and establish its influence on a global scale. China's ambitious progress in this sector therefore requires a deep understanding of countries' innovative capacities and goals. The United States had to put in a considerable effort to pass AI.

\section{Conclusion}

We are moving towards a sharing of influence between China and the United States in the field of cyber space and AI, in which Europe, alongside other regions of the world, can only note their powerlessness. China has the ambition to become a full player in the regulation of AI. It is high time to put an end to the situation where the developed countries monopolize the definition of the international standards which the developing countries are obliged to obey, under penalty of isolation, even exclusion. This subject must be kept up to date, to know whether China will approach this development in a spirit of cooperation or confrontation.

We have mentioned above how China and the United States have used their technological capabilities in general and in the field of artificial intelligence in particular, most of which are aimed at achieving the geopolitical and military interests of the country. In other words, artificial intelligence is the weapon of the present age.

But today we face a unique and serious challenge, which is an obstacle to achieving the goals of both countries. Where the appearance of the Covid 19 Virus at the end of 2019, which began to spread in the Chinese city of Wuhan, changed future expectations today and exacerbated the conflict in Sino-US relations, especially after President Trump's statement describing Covid19 as "the Chinese virus". Today we are uncertain whether

${ }^{20}$ Ecofin Agency, published in 2020. 
Financial Markets, Institutions and Risks, Volume 4, Issue 3, 2020 ISSN (online) - 2521-1242 ISSN (print) - 2521-1250

China will meet the targets of the artificial intelligence development plan presented in 2017 and whether Trump's policies will succeed in raising the level of American technology. In fact, there is no clear and explicit answer.

The challenge is therefore more difficult. Trump cannot impose new sanctions on China to escape the epidemic, and China will not succeed if it expands its international relations and increases its military forces in the fight against this virus. Danger faces everyone, even the leader cannot escape. The question now is whether the direction of artificial intelligence will change. Will the two countries use their artificial intelligence capabilities to fight the Corona epidemic? Or will its role be limited to the realization of geopolitical interests?

Author Contributions: conceptualization, Hassan Obeid ; methodology, Rana Fakih ; validation, Kholoud Mozannar ;formal analysis, Fatima Hillani; investigation, Rana Fakih, Kholoud Mozannar, Fatima Hillani; resources, Rana Fakih, Kholoud Mozannar, Fatima Hillani ; data curation, Rana Fakih, Kholoud Mozannar); writing - original draft preparation, Rana Fakih, Kholoud Mozannar, Fatima Hillani ; writing review and editing, Hassan Obeid; visualization, Rana Fakih, Kholoud Mozannar, Fatima Hillani ; supervision, Hassan Obeid ; project administration, Hassan Obeid.

\section{References}

1. Brezillon, P. (1999). Context in Artificial Intelligence: I. A Survey of the literature, LIP6, Case 169, University Paris 6, 4 place Jussieu, 75252 Paris Cedex 05, France. Retrieved from: https://www.researchgate.net/profile/Patrick Brezillon/publication/220106390 Context in Artificial In telligence I A Survey of the Literature/links/0fcfd50cb6dbdeb89f000000.pdf

2. Bundy, A. (2017). Ai \& Society 32(2), Preparing for the future of Artificial Intelligence, 285-287. Retrieved from: https://d1.acm.org/doi/10.1007/s00146-016-0685-0

3. Cabannes, J., Wang, J. (2011). Chinese surpluses and American deficits: A change in global imbalances, Financial economics association "Financial economics review", Electronic distribution Cairn.info, 151155. Retrieved from: https:/www.cairn.info/revue-d-economie-financiere-2011-2-page-151.htm

4. ÇalÕúkan H. (2015). Technological Change and Economic Growth, Procedia-Social and Behavioral Sciences. Retrieved from: https://www.researchgate.net/publication/282556898 Technological Change and Eco nomic Growth

5. Development Plan for the Next Generation of Artificial Intelligence. (2017). Retrieved from: https://chinacopyrightandmedia.wordpress.com/2017/07/20/a-next-generation-artificial-intelligencedevelopment-plan/

6. Easterbrook, S.M, Beck, E.E., Goodlet, J.S., Plowman, L., Sharples, M., Wood, C.C. (1993). A Survey of Empirical Studies of Conflict. In: Easterbrook S. (eds) CSCW: Cooperation or Conflict? Computer Supported Cooperative Work, Springer, London. Retrieved from: https://doi.org/10.1007/978-1-44711981-4 1

7. Fischer and Sophie-Charlotte, Artificial intelligence: China's ambitions. (2018). Center for Security Studies (CSS), ETH Zurich, 1-4. Retrieved from: https://www.research-collection.ethz.ch/handle/ 20.500. $11850 / 321545$

8. Gendreau, L. (2019). BATX Growth Still Much Higher Than GAFA Growth, HUB Institute. Retrieved from: https:/hubinstitute.com/2018/transformation/infographie-Baidu-Alibaba-Tencent-Xiaomi-capita lisa tion-gafa

9. Gilles Vandal, America in the Age of Artificial Intelligence. (2019). The Daily, electronic publication. Retrieved from: https://www.lesoleil.com/chroniques/gilles-vandal/lamerique-a-lere-de-lintelligenceartificielle-e31bc815faa62fc0b5eab9c0ea67beb4

10. Kai-Fu, L. (2018). AI Superpowers, China, Silicon Valley and the New World Order, New York, Houghton Mifflin Harcourt Publishing Company, 43.

11. Kissinger H., (2018). How the Enlightenment Ends, The Atlantic. Retrieved from: https://www.theatlantic.com/magazine/archive/2018/06/henry-kissinger-ai-could-mean-the-end-ofhuman-history/559124/

12. Meneut, Em. (2017) Cyberspace and Chinese nationalism: the lever of a great digital power, Asia Focus, February. Retrieved from: https://www.iris-france.org/wp-content/uploads/2017/02/Asia-Focus-17Cyber-space-China-Feb-2017.pdf

13. Meng, J. (2018). Here's what China is doing to boost its artificial intelligence capabilities, South China Morning Post, May 10. Retrieved from: https:/www.scmp.com/tech/science-research/article/ 21 45568/can-trumps-ai-summit-match-chinas-ambitious-strategic-plan 
14. Mommaerts, C. (2019). The United States and China, champions of artificial intelligence", L'Echo newspaper, February 01, 2019. Retrieved from: https://www.lecho.be/tech-media/technologie/les-etatsunis -and-china-champions-of-artificial-intelligence / 10093372.html

15. National Research Council, Maximizing U.S Interests in Science and Technology Relations with Japan. (1997). Chapter 3: Science, Technology, and Innovation in the United States, 45-51. Retrieved from: https://www.nap.edu/read/5850/chapter/1

16. Nelson, R., Wright, G. (1992). The Rise and Fall of American Technological Leadership: The Postwar Era in Historical Perspective, Journal of Economic Literature 30 (4). Retrieved from: https://www.jstor.org /stable/2727970?seq $=1$

17. Nye, J. (2003). The Paradox of American Power": Why the Only Superpower Can't Go it Alone, Foreign politics, 2003, 849-850. Retrieved from: https://www.researchgate.net/publication/276029052 The Paradox of American_Power_Why the World $\% 27 \mathrm{~s}$ _Only_Superpower_Can $\% 27 \mathrm{t}$ Go It Alone

18. Olsher. D. J. (2015). New Artificial Intelligence Tools For Deep Conflict Resolution and Humanitarian Response, Integral Mind Technologies, Washington DC, United States, 10. Retrieved from: https://www.alnap.org/system/files/content/resource/files/main/deep.pdf

19. Ronald Fraser, Mastering a New Role: Shaping Technology Policy for National Economic Performance (1994). Chapter 3: Strengths and Weakness of the US Technology Enterprise, Journal of Policy Analysis and Management 13 (3), 61-69. Retrieved from: https://ideas.repec.org/a/wly/jpamgt/v13y1994i3p610614.html

20. Secure 5G: The Eisenhower National Highway System for the Information Age, National Security Council of the United States of America. (2017). Retrieved from: https://docs.house. gov/meetings/IF/IF16/20180130/106810/HHRG-115-IF16-20180130-SD1011-U10 11.pdf

21. Shirky, C. (2011). The Political Power of Social Media: Technology, The Public Sphere, And Political Change, 1-3. Retrieved from: https://www.cc.gatech.edu/ beki/cs4001/Shirky.pdf

22. Thibout, Ch. (2019). The Global Artificial Intelligence Competition, Powers, Electronic Distribution Cairn.info, 131-142. Retrieved from: https:/www.cairn.info/revue-pouvoirs-2019-3-page-131.htm

23. Vermander, B. China and the United States, Partners and Competitors (2003). S.E.R, Electronic Distribution Cairn.info, 453-456. Retrieved from: https://www.cairn.info/revue-etudes-2003-11-page$\underline{453 . h t m}$

24. Vtincza, J. (1999). Artificial intelligence support in design: A survey, University of Twente, Enschede, The Netherlands, 57. Retrieved from: https://link.springer.com/chapter/10.1007/978-94-017-1901-8 3

25. Xavier Seurre, Artificial intelligence, a strategic issue for the Chinese power, Institute of International and Strategic Relations, 2-22. Retrieved from: https://www.iris-france.org/wp-content/uploads/2020/02/AsiaFocus-132.pdf 